\title{
UPPER PRECAMBRIAN DOLOMITES FROM CRISÓPOLIS (BAHIA): CHEMICAL AND PETROGENIC STUDY
}

\author{
GIAN PAOLO SIGHINOLFI*, GERALDO DA SILVA VILAS BOAS**; \\ SILVIO DE QUEIROZ MATTOSO* and CARLO GORGONI***
}

\begin{abstract}
The Crisopolis dolomite, Northern Bahia, occurs in a limited vertical sequence of predominantly dark-coloured compact dolomite strata containing minor beds of lighter oolith-rich siliceous dolomite and rare chert partings. This sequence, believed to be of Upper Precambrian age, has undergone low-grade metamorphism. Mineralogically, the rocks consist of dolomite, quartz and talc. Chemical data show an overall abundance of silica with clear signs of metasomatic diffusion in the compact dolomite strata. Sodium content decreases as silica metasomatism increases. Detrital and/or hydrolized elements like $\mathrm{Fe}, \mathrm{Mn}, \mathrm{Ti}, \mathrm{Zr}$ and $\mathrm{K}$ are present in minor amounts. A model for the genesis of the dolomite proposes:

a) deposition of primary $\mathrm{CaCO}_{3}$ and magnesian calcite from water which is probably a little hypersaline;

b) dissolution of primary carbonates at lower $\mathrm{pH}$ conditions and reprecipitation of dolomite with extensive sweating out of more soluble $\mathrm{CaCO}_{3}$;

c) contemporaneous silica precipitation and its metasomatic diffusion during the diagenetic stage.

A paleo-environmental model is proposed. Accordingly, the primary carbonate deposition would have occurred in an intertidal zone and the dissolution-reprecipitation stabilization of carbonates related to the interference of meteoric waters.
\end{abstract}

RESUMO As rochas dolomíticas de Crisópolis, nordeste da Bahia, ocorrem em uma seqüência vertical limitada, consistindo predominantemente de camadas compactas de dolomito escuro contendo finas camadas mais claras de dolomito silicoso oolítico e raras concreções silicosas. Essa seqüuência é presumivelmente de idade pré-cambriana superior e apresenta um metamorfismo de baixo grau. Mineralogicamente as rochas são constituídas principalmente de dolomita, quartzo e talco. As camadas compactas de dolomito apresentam uma abundância de sílica com evidências claras de difusão metassomática. $\mathrm{O}$ teor em sódio diminui com o aumento da sílica metassomática. Os elementos detríticos e/ou hidrolizados, como o $\mathrm{Fe}, \mathrm{Mn}, \mathrm{Ti}, \mathrm{Zr}$ e $\mathrm{K}$, estão presentes em quantidade menores. Um modelo genético da dolomita propõe:

a) deposição de $\mathrm{CaCO}_{3}$ e calcita magnesiana a partir da água, que é provavelmente um pouco hipersalina;

b) dissolução dos carbonatos primários em condições de pH mais baixas e reprecipitação de dolomita com extensa exsudação do $\mathrm{CaCO}_{3}$ mais solúvel;

c) precipitação contemporânea da sílica e difusão metassomática da mesma durante o estágio diagenético.

É proposto um modelo paleoambiental, segundo o qual a deposição do carbonato primário teria ocorrido em uma zona intermaré. A dissolução bem como a reprecipitação e estabilização dos carbonatos estariam relacionadas com a ação de águas meteóricas.

*Instituto de Geocièncias da UFBa, Salvador (BA)

**Programa de Pesquisa e Pós-Graduação em Geofísica, Instituto de Geocièncias da UFBa, Salvador (BA)

***Istituto di Mineralogia, Universitá di Modena, Modena, Itália 
INTRODUCTION Precambrian dolomitic carbonate rocks are widespread in the Bahia State. Genetically, they may be divided into three main groups: the first comprises recrystallized impure carbonate rocks incorporated in the Archean-Lower Proterozoic basement formations; the second group consists of an extremely extensive group (the Bambuí Group) of Upper Precambrian age stretching in a N-S and E-W direction in North-Central Bahia; the third group comprises minor carbonate sequences widely distributed in Upper Precambrian formations. No mineralogical or chemical data whatsoever are available on this last group of carbonate rocks, and its genesis is accordingly unknown,

This paper presents mineralogical and chemical data on a minor dolomitic sequence occurring near Crisópolis, and offers a genetic interpretation. The findings of the present study may also throw light on the genesis of other Upper Precambrian carbonate formations, including the extremely important Bambui Group.

GEOLOGICAL NOTES The carbonate sequence in question outcrops near Crisópolis, northern Bahia, Brazil.

It corresponds to the bottom of Estância formation (Allard e Tibana, 1963), probably of the Upper Precambrian age, correlated to the Bambui Group (Humphrey e Allard, 1969). Dolomitic rocks have been found resting directly on the Lower-Precambrian basement.

The sequence studied is about $60 \mathrm{~m}$ thick and consists of a sucession of larger compact dolomitic strata varying in thickness between 0,5 and $2 \mathrm{~m}$ and interlayered with thinner, lighter dolomites. Thin layers of light grey-coloured material of schistous aspect are sometimes present on top of the massive dolomite strata. The colour of the dolomitic rocks varies from light-grey to dark-grey, even within a single dolomite stratum (see the Fig. 1). Chert partings are rare and irregularly distributed.

Structures of Collenia algae (Allard e Tibana, 1963; Humphrey e Allard, 1969) are visible in some outcrops.

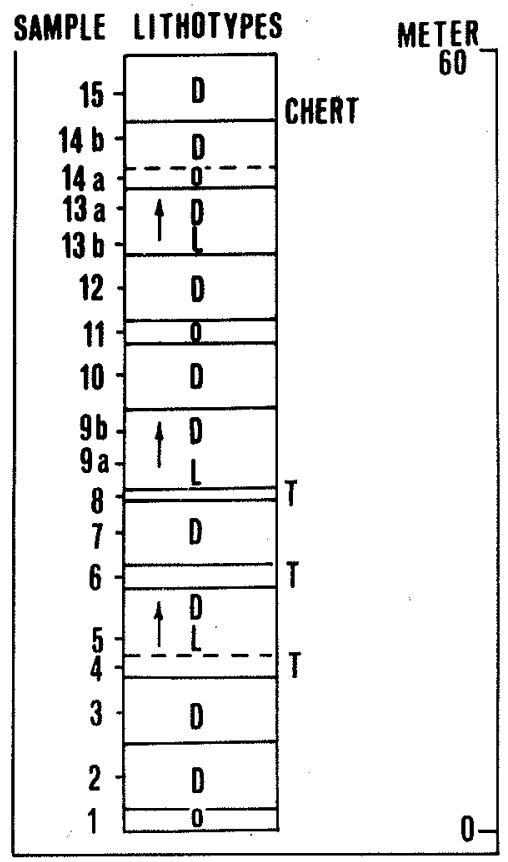

Figure 1 - Sketch map of the stratigraphic column of the Crisópolis dolomite. $D=$ = dark dolomite; $L=$ light dolomite; $T=$ talcous level; $O=$ oolith-rich level 
MINERALOGIGAL AND PETROGRAPHIG FEATURES 22 samples, including massive dolomites, oolith-bearing samples and schistous material were studied. 19 samples (including a chert sample, GR 16) were taken from the above-described sequence. They are numbered according, to their point of collection starting from the bottom of the formation (Fig. 1). The remaining three samples were collected from other carbonate series in neighbouring areas. In thin section, massive dolomites are seen to consist of a mixture in varying proportions of a microcrystalline matrix and of larger carbonate and quartz crystals. Ooliths, pellets, etc. may be present in general as fragments but are relatively rare.

Recrystallization of the microcrystalline matrix and of the larger crystals is frequently advanced or total, thus making it impossible to deduce with any accuracy the nature of the original material. Quartz is present in large quantities in most parts of the formation, so it can be called siliceous dolomite. Quartz crystals do not exhibit detrital features but are present in the form of well-crystallized grains which fill the pores and microfractures of the rock, cement crystals of different nature and replace previous structures (dolomite crystals, ooliths, etc.). In some cases, the quartz content varies progressively within a massive stratum. More frequently, it varies discontinuously, as can be observed macroscopically, the more siliceous dolomites being light in colour.

Several features indicate that the metasomatic silica diffusion was a relatively early process occuring during a diagenetic stage, as has frequently been observed (Ingerson, 1962). Dolomite is also largely recrystallized both in the fine micritic matrix and as larger crystals. Analysis by X-ray diffraction indicates that carbonates consist wholly of dolomite. While detrital quartz is practically absent, in some samples (GR 9 and GR 10) fragments of dolomite crystals with detrital features are recognizable. In these samples, remnants of material of probable organogenic origin, like pellets and algal fragments, are also visible. Three strata of light-coloured dolomite (CR 1, CR 11 and CR 14a) are extremely rich in ooliths which have largely been replaced metasomatically by quartz:

Those not metasomatized present radial or concentrical structures. Post-depositional processes that might have introduced mineralogical changes include diagenesis and low-grade metamorphism. Talc, which is everywhere present in the massive dark-or light-coloured dolomite and schistous interlayers, is, of course, of metamorphic origin. Alignments of talc crystals frequently develop at the contact between fine readsorbed quartz-rich layers and dolomite. It is the end product of a metamorphic reaction of the type:

$$
3 \text { dolomite }+4 \text { quartz }+1 \mathrm{H}_{2} \mathrm{O} \rightarrow 1 \text { talc }+3 \text { calcite }+3 \mathrm{CO}_{2}
$$

the experimental conditions of which are known (Metz and Trommsdorff, 1968; Turner, 1967; Thompson, 1975). Talc is strongly concentrated in the sample CR 8, which is a thin schistous layer a few $\mathrm{cm}$ thick sandwiched between two large dolomite strata.

GEOCHEMICAL PATTERNS Geochemical data for 22 samples (including a chert sample) are reported in Table 1. Major variations in the chemistry of carbonate rocks are related to the percentage of the non-carbonate fraction and also involve the $\mathrm{Ca} / \mathrm{Mg}$ ratios. Most of the samples that consist largely of carbonates have molecular $\mathrm{Ca} / \mathrm{Mg}$ ratios a little below unity. The $\mathrm{Ca} / \mathrm{Mg}$ ratios decrease markedly in the silica-rich samples (Fig. 2) thus confirming the strong magnesian character of the entire formation. As regards elements other than $\mathrm{Ca}$ and $\mathrm{Mg}$, the geochemistry of carbonate rocks is complicated by the observation (e.g. Graf, 1962) that most of these elements strictly depend on the non-carbonate materials that may have been deposited with carbonates by any one of several different processes, for it may have been incorporated in carbonates either as a detrital component, 
Table I - Main features and chemical data for the Crisópolis carbonate rocks

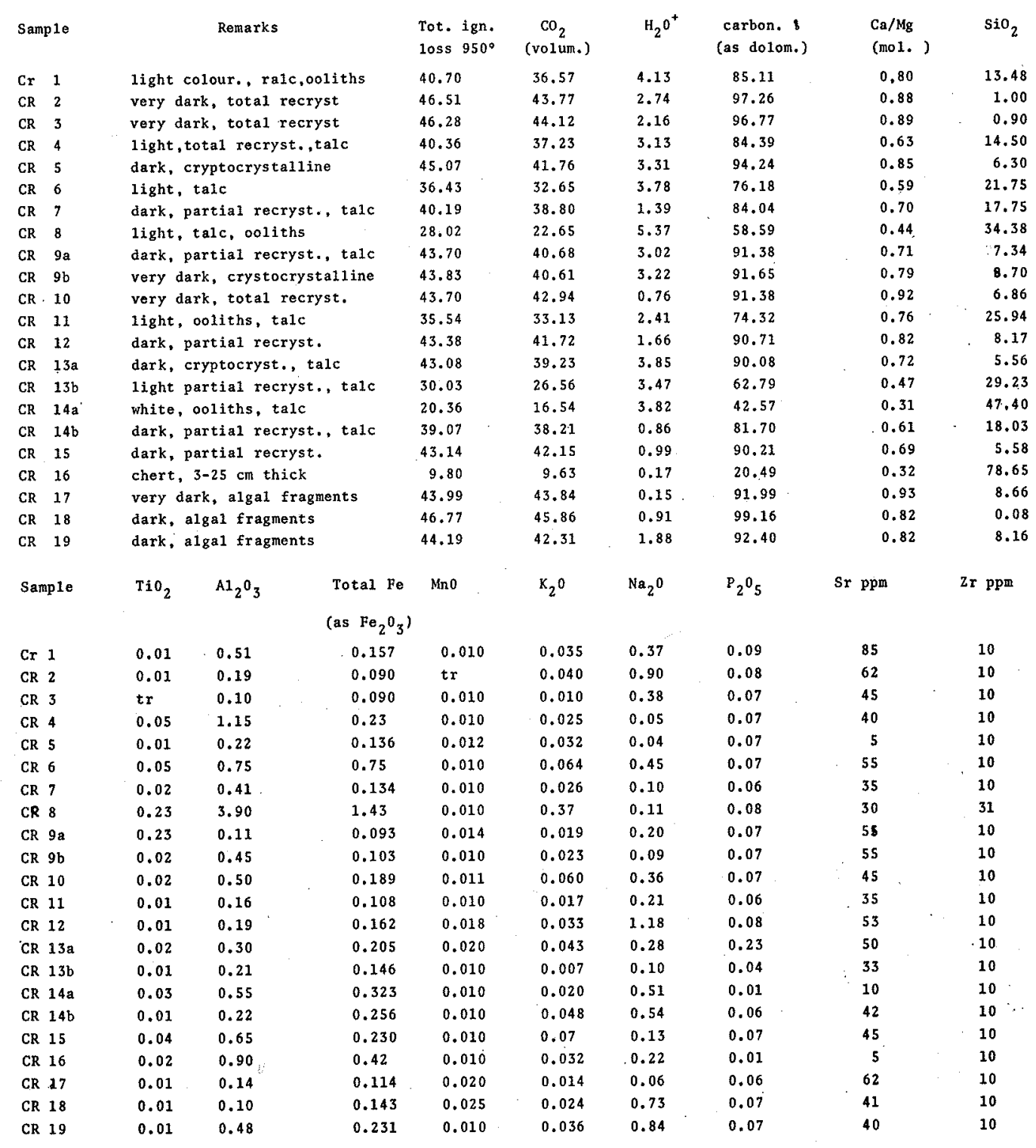

or by chemical precipitation from sea water in a simple or complex ionic form, or by biochemical mechanism. The elements typical of the hydrolizates like $\mathrm{Al}, \mathrm{Fe}, \mathrm{Ti}$ and $\mathrm{Zr}$ probably derive from small quantities of terrigeneous material, incorporated in the carbonates. The highest concentrations of $\mathrm{Fe}$ and $\mathrm{Mn}$ in carbonate rocks are frequently associated with clastics of land derivation (Button, 1974). On the other hand, they may, together with other divalent element ( $\mathrm{Zn}, \mathrm{Cd}$, etc.), be present in sea water as dissolved carbonates and co-precipitate with $\mathrm{CaCO}_{3}$ because of their lower solubilities (Crocket and Winchester, 1966). 
Figure 2-Variation of the molecular $\mathrm{Ca} / \mathrm{Mg}$ ratio with silica content

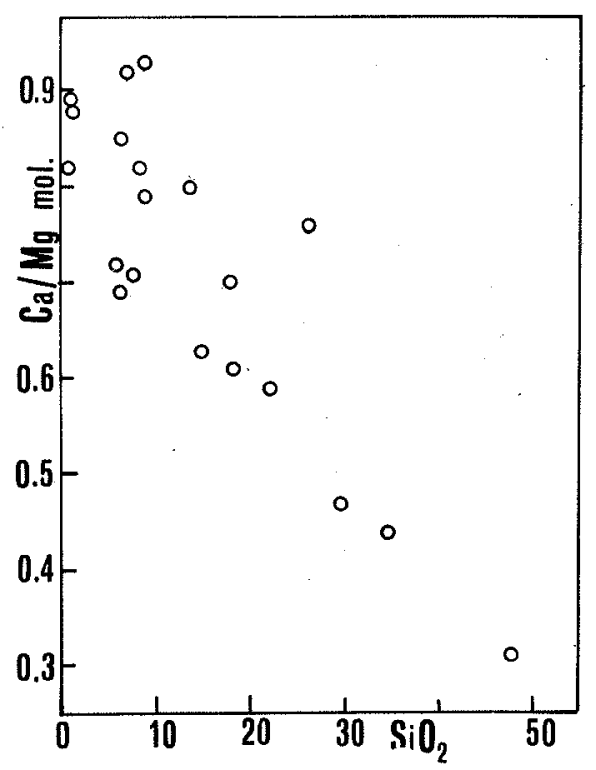

The concentration of these elements in sea water may thus be controlled by their carbonate form instead of by precipitation as pure compounds, as has been suggested (Krauskopf, 1956; Goldberg, 1967), or by organic complexing and biochemical mechanisms. In the case of the Crisópolis dolomite, iron is roughly but significantly correlated with alumina, a compound known to be related to the hydrolizate fraction. This seems to exclude the possibility of iron being chemically precipitated with calcium from sea water, as sometines suggested (Truswell and Eriksson, 1975). A remarkable feature of the present carbonates when compared with other carbonates with similar silica content (see e.g. Weber, 1964 a; Turekian and Wedepohl, 1961; Graf, 1962), is the scarcity in most samples of elements of the non-carbonate fraction ( $\mathrm{Al}, \mathrm{Ti}, \mathrm{K}$, etc.). This poses problems concerning the origin of the silica which will be discussed later. Sodium (average content $0,27 \%$ ) is markedly higher than in other dolomites and dolostones (Weber, 1964a), and since most of it (sodium) cannot be genetically correlated to the limited non-carbonate fraction it may have been precipitated from seawater of somewhat higher salinity, a situation often suggested by stratigraphic and paleogeographical studies (Weber, 1964b). In this case, appreciable amounts of sodium may remain trapped in the liquid inclusions of the sediments. It is worthy of note that in the massive dolomite strata the sodium content, normaly decreases as silica increases, an observation that will have a bearing on the discussion of the silicification process of the Crisópolis dolomite. Strontium abundances (average content $42 \mathrm{ppm}$ ) are notably less than the concentration ranges found in limestones (Graf, 1962) and dolostone (Weber, 1964a). It should be noted that depletion of strontium in carbonate rocks seems to characterize every recrystallization process of primary crystallized carbonates, both in the sedimentary diagenesis and in metamorphic recrystallization (Robinson, 1971; Thompson, 1972). Sample Cr 8 contains much more $\mathrm{Al}, \mathrm{Fe}$ and $\mathrm{K}$, which have probably been derived from terrigenous compounds brought into the sedimentary basin as fine argillaceous material.

GENESIS AND POST DEPOSITIONAL HISTORY OF THE GRISÓPOLIS DOLOMITE The crucial points to be investigated in the genetical reconstruction of the Crisópolis dolomite are: a) the environmental conditions for the primary precipitation 
of carbonates, b) its conversion into dolomite, c) the origin of the silica and d) the mode of metasomatic silicification of previous carbonates. The dependence of the $\mathrm{Ca} / \mathrm{Mg}$ ratio on the silica content of the rock indicates that the genetical process of the present carbonates was closely connected with silicification. The origin of the sedimentary dolomite has long been and still is a controversial subject. Geological and isotopic studies (see e.g. Degens and Epstein, 1964; Weber, 1964b) indicate that dolomite would have formed in the initial stages of salt deposition or in the diagenetic stages. Two main hypotheses must be considered: a) direct precipitation of dolomite from sea water under evaporitic conditions (Ingerson, 1962; Peterson et al., 1963; Weber, 1964b) or from hypersaline brines (Friedman and Sanders, 1967). In this context it should be noted that high $\mathrm{Mg} / \mathrm{Ca}$ ratios of solutions are also thought to favour primary precipitation of dolomite (Sass, 1965; Lebedev, 1965), and additional findings (see e.g. Glover and Sippel, 1967; Clayton et al., 1968) confirm the possibility of primary precipitation of dolomite in lagoonal or lacustrine environments even under non-evaporitic conditions; b) some sort of metasomatism of preexisting calcium carbonates. This hypothesis is strongly supported by carbon and oxygen isotope data (Degens and Epstein, 1964).

The difficulty of forming dolomite structures even hydrothermally (Epstein et al., 1962) suggests that dolomite does not crystallize in a finite time. For this reason, most authors retain that all low temperature dolomites are secondary. Opinions differ as to how dolomitization proceeds. It is generally accepted that primary carbonates precipitating from sea waters under alkaline conditions are aragonite and high-magnesium calcite. Thermodynamic considerations show that dolomite is stable in normal sea water at $25^{\circ}$ with respect to $\mathrm{CaCO}_{3}$ and magnesian calcites. According to Truswell and Eriksson (1975), stabilization takes place via one of the following diagenetic processes:

i) the earliest carbonates underwent dissolution because of a lowering of the environmental $\mathrm{pH}$ and replacement and reprecipitation as calcite and/or dolomite took place;

ii) aragonite in the solid state to calcite, or high-magnesium calcite exsolves to calcite and dolomite (Land, 1967);

iii) the replacement dolomitization process is enhanced by an increased $\mathrm{Mg} / \mathrm{Ca}$ ratio of the dolomitizing solutions.

The first hypothesis is of greater interest in that it has a bearing on the behaviour of silica. In conditions conducive to the precipitation of carbonates, amorphous silica is soluble, particularly at pH's values above 8 (Eugster and Ming Chow, 1973). The pH of the interstitial waters of carbonate sediments is above 9 (Krauskopf, 1967), hence they contain large quantities of dissolved silica (Emery, 1960). If, during dolomitization the environmental $\mathrm{pH}$ is lowered, silica becomes saturated in solution and precipitated as calcedonic silica or quartz, depending on their absolute concentration in solution (Versey, 1939; Kolodny et al., 1965; Oldershaw, 1968). The rare replacement cherts present in the Crisópolis series are probably related to such a mechanism. Regarding the massive proportions of silica present throughout the entire carbonate series, a number of observations lead one to exclude the possibility of its having been precipitated from the interstitial waters of the sedimentary pile. Firstly, the amount of silica present is far in excess of that suggested by silica solubility data in marine waters (Krauskopf, 1956). Secondly, the inverse correlation between silica and sodium (being this last element have been trapped in the interstitial waters) proves that silica metasomatism proceeds with the expulsion of interstitial water. The bulk of the silica must, therefore have an origin foreign to the carbonate sediments. A number of hypotheses regarding the origin of the silica can be put forward: 
1. silica was brought into the sedimentary basin as fine detrital quartz of land-derivation;

2. soluble silica was removed by biological uptake (Okamoto et al., 1957) involving phytoplankton and the species Diatomeaes and Radiolaria, which are widespread in extremely varied habitats (Parea, 1970) Siliceous skeletals may then have precipitated directly into the carbonate mud or may have been dissolved and later precipitated as colloidal silica, depending on physical variables $(\mathrm{pH}$, concentration, etc.);

3. at the boundary between continental and marine waters silica was inorganically removed by adsorption in suspended solid or colloidal material (Huang, 1975).

The first hypothesis, namely that the bulk of silica is of continental derivation, and which at first sight affords the simplest explanation, fails to take into account the fact that silica is not accompannied by discrete amounts of other detrital elements.

A point of a certain interest is the fact that the silica - rich samples are much more strongly magnesian in character than pure carbonate rocks. This correlation cannot be easily explained. The causes must clearly be sought in the particular conditions of the primary deposition of carbonates or in the diagenetic process, for lowgrade metamorphism is incapable of introducing such pronounced changes in the $\mathrm{Ca} / \mathrm{Mg}$ ratio of carbonate rocks.

A PALEO-ENVIRONMENTAL MODEL In the case of the Crisópolis dolomites, any paleo-environmental reconstructions, based on Irwin's (1965) limestone shelf model, must take into account the strongly magnesian character of carbonates, the presence of a great amount of silica and the significance of the non-carbonate fraction. In general, strongly magnesian marine waters which may determine low values for the $\mathrm{Ca} / \mathrm{Mg}$ ratio of carbonates are encountered in shallow epeiric seas of high surface to volume ratio (Gaines, 1968). Similar environments (shallow-water areas and evaporitic settings) are also the preferred removal sites for silica (Holland, 1972). The proposed mechanisms for dolomite formation, silica precipitation and silificication of carbonates imply variations in the environmental $\mathrm{pH}$ conditions during the deposition and diagenetic stages of carbonates. The establishment of the causes that have produced such variations in the $\mathrm{pH}$ is fundamental for the choice of a paleo-environmental model. Displacement to more acid pH may occur when the earliest carbonates either become subaerially exposed (Purdy 1965), or come into contact with meteoric waters (Blatt et al., 1972; Badiozamani, 1973). According to Truswell and Eriksson (1975), dolomitization may occur both in the subtidal and intertidal zone of Irwin's model. In the subtidal zone, the interstitial waters remain alkaline in character, dissolution of the earliest carbonates and precipitation of silica thus being rendered difficult. This means that dolomitization rarely enhances saturation and the rock is essentially silica free. In the intertidal zone, dolomite saturation would be achieved through an influx of meteoric waters which would favour, on one hand, the dissolution of the earlies carbonates (Badiozamani, 1973) and on the other, the precipitation of silica. From this it is evident that an intertidal zone is the most suitable for the formation of the Crisópolis carbonate series. The presence of fragmented material and of thin oolith-rich layers within the massive carbonate strata indicate that the primary deposition of carbonates underwent interruptions in time and that, contemporaneously, material removed by erosion from the barrier of Irwin's limestone shelf model was accumulated in the interdital zone. According to such a reconstruction, water of continental provenance would have played the major role in lowering the $\mathrm{pH}$ in the carbonate basin and hence in accelerating the diagenetic process.

Further study on the carbon and oxygen isotopic composition of the dolomitic rocks might serve to verify the validity of the proposed model. 
ANALYTICAL NOTES The element iron, $\mathrm{Mn}, \mathrm{K}$ an $\mathrm{Na}$ were determined by atomic absorption spectroscopy. Other major and trace elements were determined by X-ray fluorescence according to Franzini and Leoni (1972). Loss on ignition at $950^{\circ}$ was determined on 2-g samples. Volumetric determination for $\mathrm{CO}_{2}$ were made.

Acknowledgments Financial support for this research was provided by the "Convênio UFBa-FINEP-CNPq" (Post-graduate program of the Department of Geochemistry), Universidade Federal da Bahia, Salvador, Bahia.

\section{REFERENCES}

AllaRD, G. O., TiBANA, P. - 1963 - Extensão Pré-Cretácea e Petrografia da Série Estância, Reconstituída pelo Estudo dos Conglomerados Cretáceos do Reconcavo. Bol. Téc. Petrobrás, 9: $17-41$

BADIOZAMANI, K. - 1973 - The Dorag dolomitization model-application to the Middle Ordovician of Wisconsin. J. Sediment. Petrol., 43: 965-984

BLATT, H., MIDDLETON, G. and MURRAY, R. - 1972 - Origin of sedimentary rocks. Prentice Hall, New Jersey, N. J., $634 \mathrm{p}$

BUTTON, A. - 1974 - A regional study of the stratigraphy and development of the Transvaal Basin in the eastern and northeastern Transvaal. Thesis, University Witwatersrand, Johannesburg (unpublished)

CLAYTON, R. N., JONES, B.F. and BERNER, R. A. - 1968 - Isotope studies of dolomite formation under sedimentary conditions. Geochim. Cosmochim. Acta, 32: 415-432

CROCKET, J.H. and WINCHESTER, J. W. - 1966 - Coprecipitation of zinc with calcium. carbonate. Geochim. Cosmochim. Acta, 30: $1093-1109$

DEGENS, E. T. and EPSTEIN, S. - 1964 - Oxygen and carbon isopote ratios in coexisting calcites and dolomites from recent to ancient sediments. Geochim. Cosmochim. Acta, 28: 23-44

EMERY, K. O. - 1960 - The sea off Southern California: a modern habitat of petroleum. John Wiley and Sons, Inc. Eds., New York, $336 \mathrm{p}$

EPSTEIN, S., DEGENS, E. T. and GRAF, D. G. - 1962 - The oxygen 'isotopic composition of coexisting calcite and dolomite. J. Geophys. Res. 67: 1636-1 637

EUGSTER, H. P. and MING GHOW, I. - 1973 - The depositional environments of Precambrian banded iron formations. Econ. Geol,, 68: $1144-1168$

FRANZINI, M. and LEONI, L. - 1972 - A full matrix correction in X-ray fluorescence analysis of rock samples. Atti Soc. Toscana Sci. Nat. Pisa Proc. Verb. Mem., 79A: 7-22

FRIEDMAN, G. M. and SANDERS, J. E. - 1967 - Origin and occurrence of dolonstones. In "Developments in sedimentology", 9B: Carbonate rocks. G. V. Chilingar, H. J. Bissel and R. W. Fairbridge, Eds. Elsevier, pp. 267-348

GAINES, A. M. - 1968 - An experimental investigation of the kinetics and mechanism of the formation of the dolomites. Thesis. Univ. Chicago, III. (unpub)

GLOVER, E. D. and SIPPEL, R. F. - 1967 - Synthesis of magnesium calcites. Geochim. Cosmochim. Acta, 31: 603-613

GOLDBERG, E. D. - 1963 - The oceans as a chemical system. In "The Sea", 2 (H. N. Hill Ed.): 3-25, Interscience

GRAF, D. L. - 1962 - Minor element distribution in sedimentary carbonate rocks. Geochim. Cosmochim. Acta, 26: 849-856

HOLLAND, H. D. - 1972 - The geologic history of sea water - an attempt to solve the problem. Geochim. Cosmochim. Acta, 36: 637-651

HUANG, C. - 1975 - The removal of aqueous silica from dilute aqueous solution. Earth Planet. Sci. Lett., 27: 265-274

HUMPHREY, F. L. and ALLARD, G. O. - 1969 - Geologia da área do Domo de Itabaiana (Sergipe) e sua relação com a geologia de Propriá - um elemento recém-reconhecido no escudo brasileiro. Petrobrás-GENPES, Div. Doc. Técnica e Patentes, $160 \mathrm{p}$ 
INGERSON, E. - 1962 - Problems of the geochemistry of sedimentary carbonate rocks. Geochim. Cosmochim. Acta, 26: 815-847

IRWIN, M. L. - 1965 - General theory of epeiric clear water sedimentation. Bull. Amer. Assoc. Petrol. Geol., 49: 445-459

KOLODNY, Y., NATHAN, Y. and SASS, E. - 1965 - Porcellanite in the Mishash Formation, Negev, Southern Israel, J. Sediment., 35: 454-463

KRAUSKOPF, K. B. - 1956 - Factors controlling the concentrations of thirteen rare metals in sea-water. Geochim. Cosmochim. Acta, 9: 1-32

KRAUSKOPF, K. B. - 1967 - Introduction to Geochemistry. McGraw-Hill, New York (N.Y.), $321 \mathrm{p}$

LAND, L. S. - 1967 - Diagenesis of skeletal carbonates, J. Sediment. Petrol., 37: 914-930

LEBEDEV, V. I. - 1965 - Calcium content and some other compositional characteristics of the Precambrian seas. Geochem. Inter., 2: $843-852$

METZ, P. and TROMMSDORFF, V. - 1968 - Om phase equilibria in metamorphosed siliceous dolomites. Contr. Mineral, and Petrol., 18: 305-309

OKAMOTO, G., OKURA, T. and GOTO, K. - 1957 - Properties of silica in water. Geochim. Cosmochim. Acta, 12: 123-132

OLDERSHAW, A.E. - 1968 - Electron-microscopic examination of Namicriam bedded cherts, North Wales (Great Britain). Sedimentology, 10: 255-272

PAREA, G. C. - 1970 - Ricerche sulla genesi delle rocce silicee non detritiche Men. Soc. Geol. It., 9: 665-707

PETERSON, M. N. A., BIEN, G. S. and BERNER, R. A. - 1963 - Radiocarbon studies of recent dolomite from Deep Springs Lake, California. J. Geophys., Res., 68: 6 493-6 505

PURDY, R. G. - 1965 - Diagenesis of recent marine carbonate sediments, In "Dolomitization and limestone diagenesis. L. C. Pray and R. G. Murray Eds. Soc. Econ. Paleontol. Mineral., Spec. Pebl. 13, p. 169

ROBINSON, D. - 1971 - The inhibiting effect organic carbon on contact metamorphic recrystallization of limestones. Contr. Mineral. and Petrol., 32: 245-250

SASS, E. - 1965 - Dolomite-calcite relationship in sea-water: theoretical considerations and preliminary experimental results. J. Sediment. Petrol., 35: 339-349

THOMPSON, A. M. - 1975 - Talc paragenesis in some siliceous dolomite rocks and its sedimentologic significance. Contr. Mineral. and Petrol., 52: 133-142

THOMPSON, G. - 1972 - A geochemical study of some lithified carbonate sediments from the deep-sea. Geochim. Cosmochim. Acta. 36: 1 237-1 253

TRUSWELL, J. F. and ERIKSSON, K. H. - 1975 - A paleoenvironmental interpretation of the Early Proterozoic Malmani dolomite from Zwartkops South Africa. Prec. Res., 2: 277-303

TUREKIAN, K. K. and WEDEPOHL, K. H. - 1961 - Distribution of the elements in some major units of the Earth's crust. Bull. Geol. Soc. Am., 72: 175-192

TURNER, F.J. - 1967 - Thermodinamic appraisal of steps in progressive metamorphism of siliceous dolomitic limestones. Neues Jahrb. Mineral., Monatsh, 1: 1-22

VERSEY, H. C. - 1939 - The petrography of the Permian rocks in the southern part of the Vale Eden. Geol. Soc. Lond., J., 95: 275-298

WEBER, J. N. - 1964(a) - Trace element composition of dolostone and dolomites and its bearing on the dolomite problem. Geochim. Cosmochim. Acta, 28: 1 817-1 868

WEBER, J. N. - 1964(b) - Carbon-oxygen isotopic composition of Flagstaff carbonate rocks and its bearing on the history of Paleocene-Eocene Lake Flagstaff of Central Utath. Geochim. Cosmochim. Acta, 28: $1219-1242$ 